\title{
Performance Analysis of VRLA Battery for DC Load at Telecommunication Base Station
}

\author{
Imelda Uli Vistalina Simanjuntak ${ }^{1 *}$, Heryanto $^{2)}$, Yossy Rahmawaty ${ }^{3)}$, and Tulus Manurung ${ }^{4)}$ \\ 1,3,4) Department of Electrical Engineering, Mercu Buana University, Indonesia \\ ${ }^{2)}$ Department of Electrical Engineering, Indonesia Defense University, Indonesia \\ Corresponding Email: ${ }^{*}$ imelda.simanjuntak@mercubuana.ac.id
}

\begin{abstract}
The high level of power outage in SukabumiCianjur area has influenced the operations of telecommunication industry in the vicinity. This has shortened the battery life at the Base Station (BTS). This study aims to analyze the performance of a (new) VRLA battery against a DC load (BTS) to support the continuity of BTS operation in case of a power outage. The research method used is a (new) battery charge-discharge procedure. Parameters are analyzed by determining the on-site battery discharge duration, the pressure at the battery terminals between cells during backup, and the capacity of the rectifier module to support fast charging. To support fast charging, the rectifier with the formula $\mathrm{N}+1$ and $\mathrm{C}$-rate is $10 \%$ and C15 is $15 \%$ of the battery capacity. The internal impedance value is $3.4 \mathrm{~m} \Omega$ and the battery terminal pressure (torque) is $9-11 \mathrm{~N} / \mathrm{m}$. The battery performance analysis of the four BTS shows that two of them managed to do a backup, while the other two did not provide good performance.
\end{abstract}

Keywords: charge-discharge, C-rate, rectifier, torque, VRLA battery

\section{INTRODUCTION}

Competition among telecommunication operators always demands excellent service for the customers. Therefore, most devices must be on standby 24 hours. The frequent power outage in Sukabumi-Cianjur area has influenced the operations of telecommunication industry. In the BTS shelter, there is a VRLA battery as backup power in case of power outage. This type of battery is very susceptible to high temperature caused by unstable electricity which can shorten its life.

Previous research aims to determine the energy efficiency of the lead acid battery through the charging process with the constant current method of $0.3 \mathrm{~A}, 0.5 \mathrm{~A}$, and $0.6 \mathrm{~A}$. Based on the test results of the chargedischarge process, the current variation of $0.3 \mathrm{~A}, 0.5 \mathrm{~A}$, and $0.6 \mathrm{~A}$ results in energy efficiency of $76.32 \%, 76.06 \%$ and $91.33 \%$, respectively[1].

A study shows that charging times can be reduced by using fuzzy logic or model prediction controls. This paper reviews the existing methods to control the charging and discharging processes, focusing on their impact on battery life [2].

A research compared some aspects between lead-acid batteries and lithium-ion batteries, the two main options for stationary energy storage. Various properties and characteristics are summarized specifically for valve regulated lead acid batteries (VRLA) and lithium iron phosphate (LFP) lithium-ion batteries. The charging process, efficiency, and life cycle are discussed for each battery type. Through a specific cost analysis, lithium-ion batteries have been proven to be a cost-effective alternative [3].

Table 1. Differences with some reference journals

\begin{tabular}{|c|c|c|c|}
\hline No. & Title & $\begin{array}{c}\text { Comparative } \\
\text { Journal }\end{array}$ & Description \\
\hline 1 & $\begin{array}{l}\text { The Effect of } \\
\text { Current Variations } \\
\text { Charge discharge } \\
\text { of Lead Acid } \\
\text { Battery for Energy } \\
\text { Efficiency }\end{array}$ & $\begin{array}{l}\text { battery } \\
\text { charging } \\
\text { method, with } \\
\text { different C-rate }\end{array}$ & $\begin{array}{l}\text { Volume 16, No } \\
1, \\
\text { Februari } 2019 \\
\text { ISSN:1829-796 } \\
\text { (print); } \\
2541-1713 \\
\text { (online) }\end{array}$ \\
\hline 2 & $\begin{array}{l}\text { A Review on } \\
\text { Battery Charging } \\
\text { and } \\
\text { Discharging } \\
\text { Control Strategies: } \\
\text { Application to } \\
\text { Renewable Energy } \\
\text { Systems }\end{array}$ & $\begin{array}{l}\text { battery } \\
\text { charging } \\
\text { method }\end{array}$ & $\begin{array}{l}\text { Energies 2018, 11, } \\
\text { 1021; } \\
\text { DOI:10.3390/en } \\
11041021\end{array}$ \\
\hline 3 & $\begin{array}{l}\text { Comparison of } \\
\text { Lead-Acid and } \\
\text { Lithium-Ion } \\
\text { Batteries for } \\
\text { Stationary } \\
\text { Storage in Off-Grid } \\
\text { Energy Systems }\end{array}$ & $\begin{array}{l}\text { Difference of } \\
\text { battery types } \\
\text { and on grid and } \\
\text { off grid } \\
\text { implementation }\end{array}$ & $\begin{array}{l}\text { IEEE - Institute } \\
\text { of } \\
\text { Electrical and } \\
\text { Electronics } \\
\text { Engineers } \\
\text { Inc. ISBN: } 978- \\
1- \\
78561-238-1 \\
\text { DOI: } \\
10.1049 / \text { cp. } 2016 . \\
1287\end{array}$ \\
\hline 4 & $\begin{array}{l}\text { Performance } \\
\text { Analysis of VRLA } \\
\text { Battery for DC Load } \\
\text { at } \\
\text { Telecommunication } \\
\text { Base Station }\end{array}$ & $\begin{array}{l}\text { Battery } \\
\text { checking and re- } \\
\text { measurement, } \\
\text { charging of new } \\
\text { batteries }\end{array}$ & Proposed \\
\hline
\end{tabular}

Based on some of the references above, this study analyzes the performance of the VRLA battery which influences the battery life so that premature replacement does not occur frequently. By charging and discharging the new battery, and predicting the battery life, simulation can be maximized. 


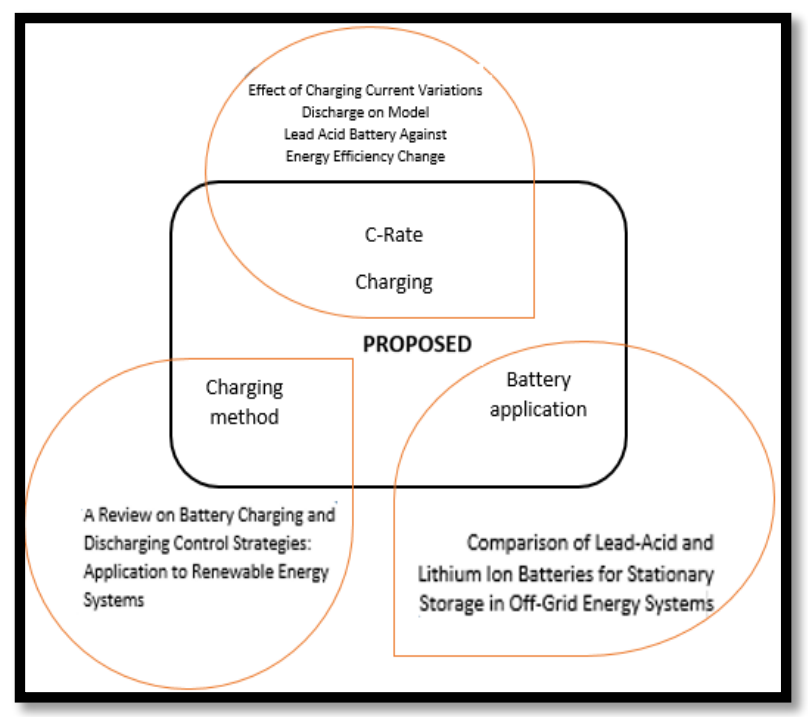

Figure 1. Research venn diagram

This study refers to three previous studies. The first reference [1] is charging analysis based on C-rate (capacity) where only 2 types of C-rate are used. The second reference [2] is the analysis of the charging methods used, i.e., the equalize and floating method. And the third reference [3] is the application of a battery that is charging and releasing energy (discharging) on the grid.

\section{Methodology}

\section{A. Definition of VRLA Battery}

A VRLA (valve-regulated lead-acid) battery is a battery with electrodes made of lead immersed in dilute sulfuric acid [4]. This battery is often called as dry batteries because of the shape and design, it can be installed in any position and do not require constant maintenance compared to wet batteries. However, the term "maintenance free" is also incorrect because the VRLA battery needs to be cleaned and undergo functional testing regularly. This type of battery is widely used in large portable electrical devices, off-grid power systems (not connected to the PLN electricity network) and others. VRLA batteries are very susceptible to high temperature as it can cause damage to battery cells [5].

\section{B. Battery Construction}

The battery structure is explained as follows.

a) Positive and negative plates

The positive and negative plates consist of the active mass and network structure of the tin-calcium alloy.

b) Separator

Non-woven glass fiber fabric with high oxidation and heat resistance offers superior electrolyte absorption and satisfactory ion retention and conductivity.

c) Electrolyte

Dilute sulfuric acid is used as a medium for conducting ions in electrochemical reactions in batteries

d) Safety valve

The safety valve opens when there is an abnormal increase in internal pressure caused by overfilling or misuse. Gas is released from the battery to bring the pressure back to normal.

e) Container and cover

The container and cover are made of ABS or PP resin, with superior strength and acid resistance characteristics. The container and lid are sealed to prevent electrolyte and gas leakage.

f) The positive and negative electrode terminals

The positive and negative electrode terminals can be tab fasten, bolt fastening, threaded post, or lead wire type, depending on the battery type. Terminal sealing is achieved by the structure which secures the long sticking adhesive path and by the strong adoption of epoxy adhesive.

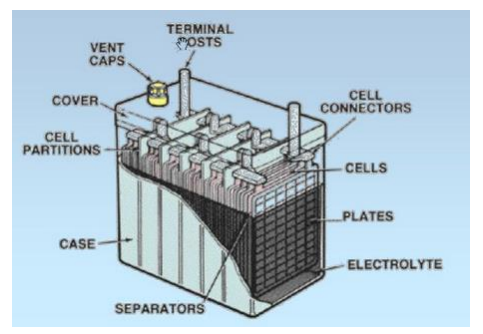

Figure 2. Battery Construction [5]

\section{Characteristics of Valve Regulated Lead Acid (VRLA) Battery}

This battery has no caps/valve, no access to electrolyte, and is totally sealed. Thus, this type of battery does not require maintenance. Deep cycle battery, is a battery that is suitable for solar cell system, because it can discharge a constant amount of electric current for a long time. Generally, deep cycle batteries can discharge up to $80 \%$ of the battery capacity. This type of battery can last for approximately 10 years with good capacity planning and maintenance [5].

Table 2. Characteristics of lead acid based on standard[6]

\begin{tabular}{ll}
\multicolumn{1}{c}{ CHARACTERISTICS } & \multicolumn{1}{c}{ LEAD ACID } \\
\hline Specific energy $(\mathrm{Wh} / \mathrm{kg})$ & $30-50$ \\
\hline Internal resistance $(\mathrm{m} \Omega)$ & very low \\
\hline Life cycle $(80 \%$ discharge $)$ & $200-300$ \\
\hline Fast-charge Time & $8-16$ hours \\
\hline $0.2 \mathrm{Copr} \mathrm{C} / 5$ & $5 \mathrm{~h}$ \\
\hline $0.1 \mathrm{C}$ or c/10 & $10 \mathrm{~h}$ \\
\hline $0.05 \mathrm{C}$ or c/20 & $20 \mathrm{~h}$ \\
\hline Overchange tolerance & High \\
\hline Self-discharge/month & $5 \%$ \\
\hline Cell voltage (nominal) & $2 \mathrm{~V}$ \\
\hline Cut-off Charge Voltage $(\mathrm{V} / \mathrm{cell})$ & 2.40 float 2.25 \\
\hline $\begin{array}{l}\text { Cut-off Discharge Voltage }(\mathrm{V} / \mathrm{cell}, \\
\text { IC) }\end{array}$ & 1.75 \\
\hline Load Peak Current & $5 \mathrm{C}$ \\
\hline Besat result & $0.2 \mathrm{C}$ \\
\hline Charge temperature & -20 up to $50^{\circ} \mathrm{C}$ \\
\hline Discharge temperature & -20 up to $50^{\circ} \mathrm{C}$ \\
\hline Maintenance & $3-6$ months \\
\hline
\end{tabular}




\begin{tabular}{ll}
\hline \multicolumn{1}{c}{ CHARACTERISTICS } & \multicolumn{1}{c}{ LEAD ACID } \\
\hline Safety & stable temperature \\
\hline Used since & around $1800 \mathrm{~s}$ \\
\hline
\end{tabular}

\section{Battery Charging}

According to Wasith dany mufty [7], there are several methods for charging batteries such as Constant Trickel (CTC), Constant Current (CC), Constant Voltage (CV), and Constant Current Constant Voltage (CC CV). Constant Current is a method of charging the battery with a constant current until the battery capacity is full. While Constant Voltage is charging the battery with a constant voltage until the battery capacity is full, more details can be seen in Figure 3 [8].

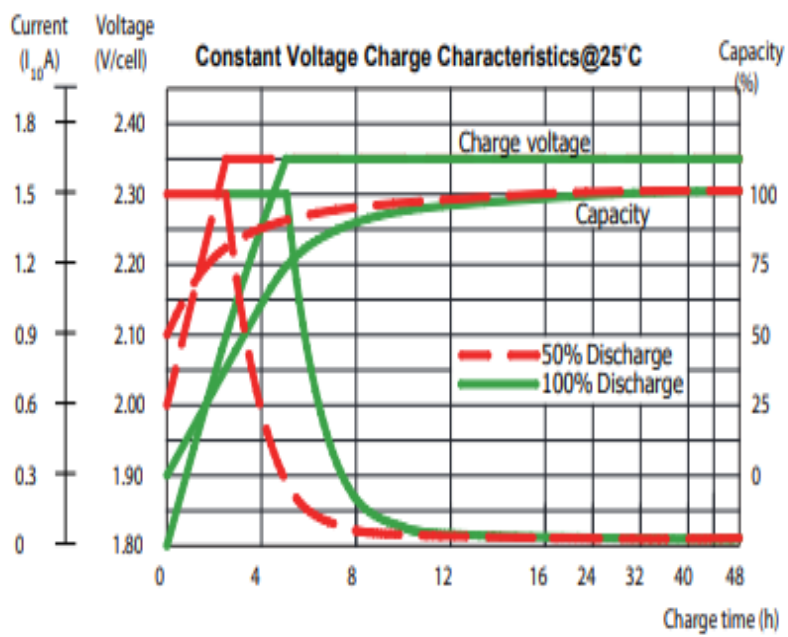

Figure 3. Characteristics of CVC (Constant Voltage Charge)

In CV (constant voltage) method, there are three stages for wet and dry batteries, i.e., absorption, equalizing, and float (tricle voltage) [9]:

1) Floating Charge, the stage of charging the battery with a constant voltage $(2.23 \mathrm{~V} /$ cell $)$ without time limit to keep the battery full.

2) Equalizing Charge, a battery charging stage to equalize the voltage on each battery cell due to the voltage difference, by providing an overvoltage $(2.35 \mathrm{~V} /$ cell $)$, but not greater than the boosting voltage.

3) Boosting Charge, is a fast-charging process carried out after the capacity test. This process is intended to charge the empty battery after the capacity test.

Acid density will vary according to temperature and state of battery charge [10]. Lead acid batteries work based on reduction and oxidation reactions of the anode and cathode materials. When the battery discharges, the active material on the electrodes reacts with the electrolyte to form $\mathrm{PbSO}_{4}$ and water, and vice versa. The basic cell reaction in a lead acid battery is described as follows:

Reaction on battery charging:

$$
2 \mathrm{PbSO}_{4}+2 \mathrm{H}_{2} \mathrm{O} \rightarrow \mathrm{Pb}+\mathrm{PbO}_{2}+2 \mathrm{H}_{2} \mathrm{SO}_{4}
$$

During the charging process, the following reactions occur [10]:

a) At the negative electrode (anode):

$$
\mathrm{PbSO}_{4}+\mathrm{H}^{+}+2 \mathrm{e}^{-} \rightarrow \mathrm{Pb}+\mathrm{HSO}_{4}^{-}
$$

b) At the positive electrode (cathode):

$$
\mathrm{PbSO}_{4}+2 \mathrm{H}_{2} \mathrm{O} \rightarrow \mathrm{PbO}_{2}+\mathrm{HSO}_{4}^{-}+3 \mathrm{H}^{+}+2 \mathrm{e}^{-}
$$

\section{E. Battery Discharging}

The battery capacity is 170 Ampere hour which means that the battery current will run out in one hour, when the load uses 170 Ampere. The recommended battery discharge level is up to 1.70 Volts per cell. The battery will be damaged if the voltage per cell is less than 1.70 Volts (or 10 Volts for 12 Volt batteries). Battery life is calculated in cycles where one cycle means one time of usage and charging. Depth of discharge (amount of battery amperage usage) affects the number of battery cycles. At 25 degrees Celsius, there are 150-200 cycles with 100 percent depth of discharge (full discharge), 400500 cycles with 50 percent depth of discharge (partial discharge), and 1000 cycles or more with 30 percent depth of discharge (shallow discharge).

The following are the chemical reactions during discharging according in the research [10]:

$$
\mathrm{Pb}+\mathrm{PbO}_{2}+2 \mathrm{H}_{2} \mathrm{SO}_{4} \rightarrow 2 \mathrm{PbSO}_{4}+2 \mathrm{H}_{2} \mathrm{O}
$$

a) Reaction at the negative electrode (anode):

$$
\mathrm{Pb}+\mathrm{HSO}_{4}^{-} \rightarrow \mathrm{PbSO}_{4}+\mathrm{H}^{+}+2 \mathrm{e}^{-}
$$

b) At the positive electrode (cathode):

$$
\mathrm{PbO}_{2}+\mathrm{HSO}_{4}^{-}+3 \mathrm{H}^{+}+2 \mathrm{e}^{-} \rightarrow \mathrm{PbSO}_{4}+2 \mathrm{H}_{2} \mathrm{O}
$$

\section{F. Rate (C-Rate)}

The rate of battery charge and discharge is set by the $\mathrm{C}$ Rate. Battery capacity is generally rated at $1 \mathrm{C}$, which means that a fully charged battery rated at $1 \mathrm{Ah}$ should provide $1 \mathrm{~A}$ for an hour. The same battery discharge at $0.5 \mathrm{C}$ should give $500 \mathrm{~mA}$ for two hours, and at $2 \mathrm{C}$ it should give $2 \mathrm{~A}$ for 30 minutes. Loss on fast discharge reduces discharge time and this loss also affects charging time.

Table 3. Comparison of C-Rate against duration

\begin{tabular}{ll}
\hline C-RATE & TIME \\
\hline $5 \mathrm{C}$ & $12 \mathrm{~min}$ \\
\hline $2 \mathrm{C}$ & $30 \mathrm{~min}$ \\
\hline $1 \mathrm{C}$ & $1 \mathrm{~h}$ \\
\hline $0.5 \mathrm{C}$ or $\mathrm{C} / 2$ & $2 \mathrm{~h}$ \\
\hline $0.2 \mathrm{Copr} \mathrm{C} / 5$ & $5 \mathrm{~h}$ \\
\hline $0.1 \mathrm{C}$ or $\mathrm{c} / 10$ & $10 \mathrm{~h}$ \\
\hline $0.05 \mathrm{C}$ or $\mathrm{c} / 20$ & $20 \mathrm{~h}$ \\
\hline
\end{tabular}

Table 3 illustrates typical times at various $\mathrm{C}$-levels. Crate $1 \mathrm{C}$ is also known as one hour discharge; $0.5 \mathrm{C}$ or $\mathrm{C} / 2$ is a two-hour discharge and $0.2 \mathrm{C}$ or $\mathrm{C} / 5$ is a 5 -hour discharge. Some high-performance batteries can be charged and discharged above $1 \mathrm{C}$ with moderate pressure.

\section{G. Rectifier}

Rectifier is a circuit system to convert AC into DC current. On site load requires a DC supply which are entirely taken from the rectifier, such as BTS, lighting in BTS, transmission, and so on. Inside the rectifier rack, there is a module to convert AC into DC current. Apart from being a current rectifier, this module also charges the battery. In principle, the rectifier will supply the power 
needed by the BTS in a fully loaded condition while maintaining the battery charge.

The battery characteristics also need to be considered in regulating the current when charging, because if a battery is recharged with a current exceeding the battery capacity limit, it can shorten the life of the battery. The charging current for a back-up battery is usually $80 \%$ of the current condition issued by the battery at full load (in an emergency or back-up condition where the electricity supply from PLN is interrupted.
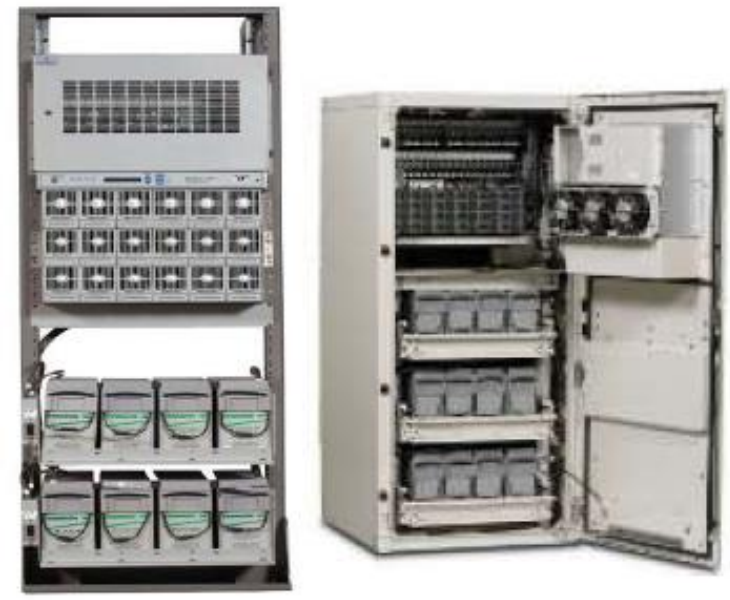

Figure 4. Indoor (left) and outdoor (right) DC rectifier for telecommunication base station

\section{H. SOP Planning Block Diagram}

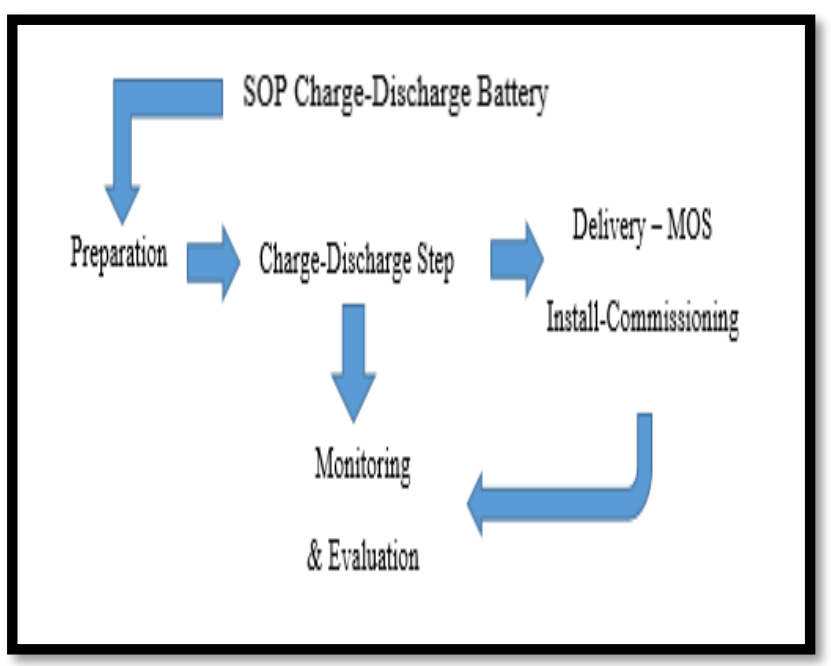

Figure 5. Block diagram of performance analysis of (new) type VRLA battery system design

Block diagram of performance analysis of VRLA battery system design against DC (BTS) load in Cianjur cluster is created by preparing SOP of battery chargedischarge process. The next stage is the charge-discharge step, followed by delivery-MOS, and the final phase is monitoring and evaluation.

\section{Data collection}

Data collection on the Battery Charge-Discharge process is shown in Figure 6 and the explanation of the parameters can be seen in Table 2 .

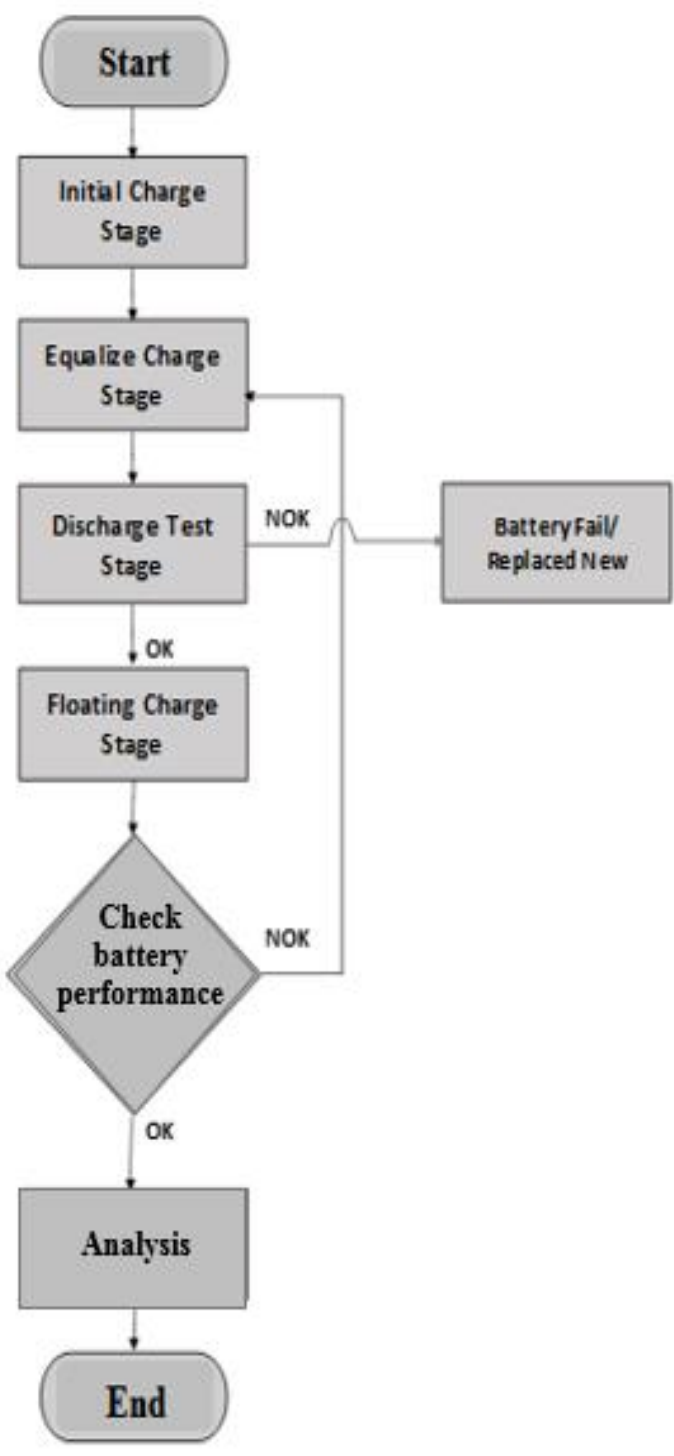

Figure 6. Data collection block diagram

\section{J. Data collection on Battery Charge-Discharge Process}

Testing of the battery charge-discharge system is carried out by assessing hardware components. Components tested include equalize charge, discharge, floating charge, internal impedance, and C-rate on the size of the rectifier module.

\section{K. Data collection from the Installation and Commissioning Process}

System testing is testing the battery installation on the rectifier rack and commissioning the battery parameters on the rectifier controller which includes, voltage, current, temperature, LLVD, BLVD, C-rate charge-discharge battery shown on figure 7 . 


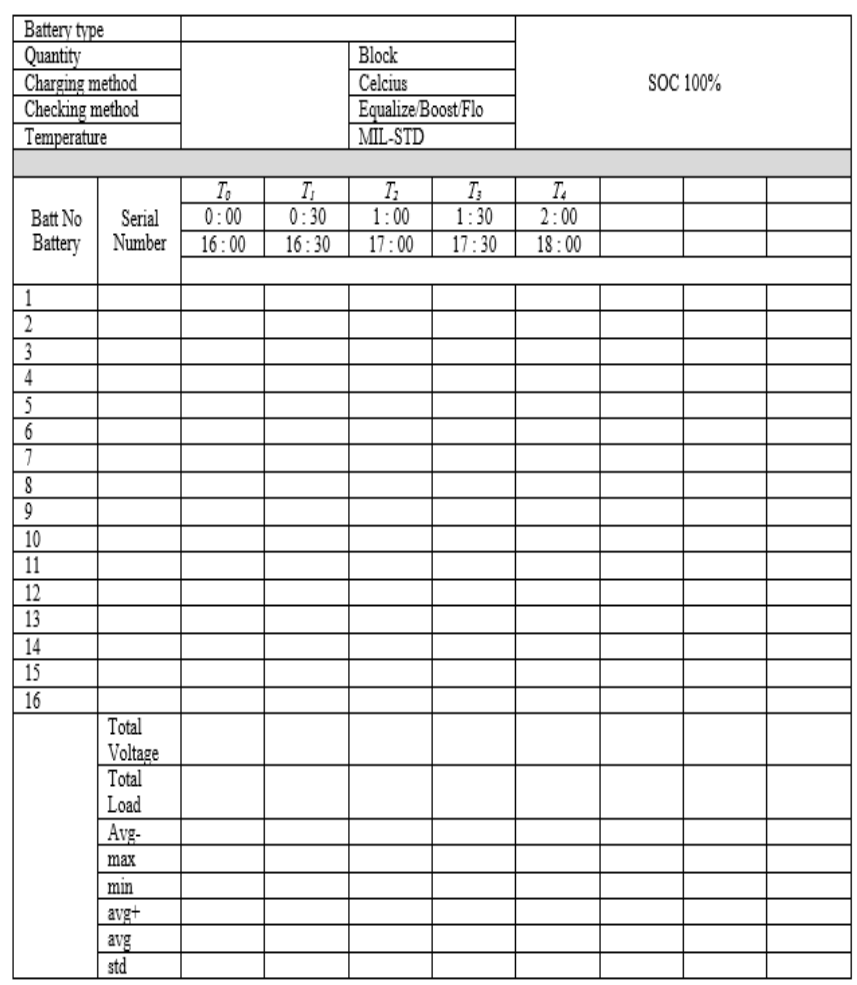

Figure 7. Battery Charge-Discharge form

\section{Data Analysis}

The analyzed data are battery charge-discharge; data and graph of equalize charge, discharge, and floating charge; internal impedance; and C-rate of the rectifier module as follows:

a) Initial charge.

b) Equalize charge, the stage of charging the battery to equalize the voltage on each battery cell.

c) Discharging, the process of emptying the battery capacity against a constant load.

d) Floating charge, the stage of charging the battery with a constant voltage $(2.23 \mathrm{~V} /$ cell $)$ without time limit to keep the battery full.

e) Internal resistance, resistance against the flow of current in the battery.

f) C-rate of the rectifier module. To charge the battery at a certain C-rate, a large rectifier capacity (as a current charger) is required according to the $\mathrm{C}$-rate.

\section{RESUlTS AND DISCUSSION}

\section{A. Charging process analysis}

The duration of charging time is influenced by the amount of charging current. The duration required for the battery charging process is indicated in Table 4.
Table 4. Technical data on battery conditions and load from a sample of four cluster sites in Sukabumi Cianjur

\begin{tabular}{lclll}
\hline & $\begin{array}{c}\text { Initial } \\
\text { Charge }\end{array}$ & $\begin{array}{c}\text { Equalize } \\
\text { Charge }\end{array}$ & $\begin{array}{c}\text { Floating } \\
\text { Charge }\end{array}$ & $\begin{array}{c}\text { Boosting } \\
\text { Charge }\end{array}$ \\
\hline $\begin{array}{l}\text { Constant } \\
\text { Current }\end{array}$ & $10.2 \mathrm{~A}$ & $13.6 \mathrm{~A}$ & $17 \mathrm{~A}$ & $17 \mathrm{~A}$ \\
\hline Duration & $20 \mathrm{H}$ & $15 \mathrm{H}$ & $12 \mathrm{H}$ & $8 \mathrm{H}$ \\
\hline
\end{tabular}

Table 4 shows the battery capacity generated during the charging process. When the charging current is greater, the stored battery capacity will also increase because when charging the charges will flow into the battery.

\section{B. Discharge process analysis (under constant load conditions)}

Table 5 summarizes the discharge duration of a battery with capacity and current of $2 \times 170 \mathrm{Ah}$ and $68 \mathrm{~A}$, respectively. The battery ability to provide backup power when the main voltage source is interrupted is defined as:

$$
\mathrm{C}=\mathrm{I} \times \mathrm{t} . \mathrm{t}=\mathrm{C} / \mathrm{I}>>(2 \times 170) / 68=5 \text { Hours }
$$

This means that the Shoto 6FMX170 battery as a backup power source at a load of $68 \mathrm{~A}$ can last approximately five hours.

Table 5. Test of battery capacity on discharge

\begin{tabular}{c|c|c|c|c|c|c|c}
\hline \multirow{2}{*}{$\begin{array}{c}\text { Battery } \\
\text { Bank }\end{array}$} & \multicolumn{7}{|c}{ Discharge Time } \\
\cline { 2 - 8 } B1-2 & 50.2 & 50.0 & 49.4 & 48.8 & 48.2 & 47.3 & 46.5 \\
\hline B3-4 & 50.2 & 50.1 & 49.4 & 48.9 & 48.2 & 47.3 & 46.6 \\
\hline B5-6 & 50.3 & 50.1 & 49.4 & 48.9 & 48.2 & 47.4 & 46.6 \\
\hline B7-8 & 50.3 & 50.1 & 49.5 & 48.9 & 48.3 & 47.4 & 46.6 \\
\hline B9-10 & 50.2 & 50.1 & 49.4 & 48.9 & 48.2 & 47.3 & 46.6 \\
\hline
\end{tabular}

\section{Battery discharge process in actual conditions on site}

The battery discharge process in the field uses the VRLA Shoto 6FMX170 type. The technical specifications of the battery are a nominal voltage of $12 \mathrm{~V}$ and a nominal capacity of $170 \mathrm{Ah} @ 10 \mathrm{Hr}$ up to $1.8 \mathrm{~V} /$ cell.

The battery is connected in series 43.2 Volt DC and the battery is connected in parallel $340 \mathrm{Ah} \mathrm{C10}$. The final capacity formed is $43 \mathrm{Volt} / 340 \mathrm{Ah} \mathrm{C10}$. The calculation result of the battery in supplying backup power is shown in Table 6.

Table 6. Technical data on battery conditions and load from a sample of four cluster sites in Sukabumi Cianjur

\begin{tabular}{clcccc}
\hline Site ID & Site Name & $\begin{array}{c}\text { Total } \\
\text { Bank } \\
\text { Qty }\end{array}$ & $\begin{array}{c}\text { Battery } \\
\text { Capacity } \\
\text { (Ah) }\end{array}$ & $\begin{array}{c}\text { Rectifier } \\
\text { Load, I } \\
(\mathbf{A})\end{array}$ & $\begin{array}{c}\text { Backup } \\
\text { Time } \\
\text { Battery } \\
\text { T= C/I } \\
\text { (hours) }\end{array}$ \\
\hline 03SMD045 & $\begin{array}{l}\text { JATI } \\
\text { NUNGGAL }\end{array}$ & 1 & $170 \mathrm{C} 10$ & 28 & 6.1 \\
\hline 03SUK079 & $\begin{array}{l}\text { MEKAR } \\
\text { SARI }\end{array}$ & 2 & $340 \mathrm{C} 10$ & 53.9 & 6.3 \\
\hline 03SUK207 & $\begin{array}{l}\text { SUKAMAJU } \\
\text { SMI }\end{array}$ & 2 & $340 \mathrm{C} 10$ & 65.3 & 5.2 \\
\hline 03CJR210 & $\begin{array}{l}\text { PASIR } \\
\text { BITUNG_TB }\end{array}$ & 2 & $340 \mathrm{C} 10$ & 33 & 10.3 \\
\hline
\end{tabular}




\section{Process battery discharge when PLN off}

Table 7. Technical data on battery conditions and load from a sample of four cluster sites in Sukabumi Cianjur

\begin{tabular}{lllll}
\hline \multicolumn{1}{c}{ Site } & $\begin{array}{c}\text { Backup } \\
\text { Duration }\end{array}$ & $\begin{array}{l}\text { Battery } \\
\text { Voltage }\end{array}$ & $\begin{array}{l}\text { Backup } \\
\text { Energy } \\
\text { Supply } \\
\text { (24 cell) }\end{array}$ & $\begin{array}{l}\text { Battery } \\
\text { perfor- } \\
\text { mance }\end{array}$ \\
\hline $\begin{array}{l}\text { Jati } \\
\text { nunggal }\end{array}$ & $4 \mathrm{H}$ & $47.7 \mathrm{VDC}$ & $\begin{array}{l}1.98 \\
\text { V/cell }\end{array}$ & Good \\
\hline $\begin{array}{l}\text { Mekar } \\
\text { sari }\end{array}$ & $4 \mathrm{H}$ & $46.2 \mathrm{VDC}$ & $\begin{array}{l}1.92 \\
\text { V/cell }\end{array}$ & Good \\
\hline $\begin{array}{l}\text { Sukamaju } \\
\text { jaya_Smi }\end{array}$ & $2 \mathrm{H}$ & $42 \mathrm{VDC}$ & $\begin{array}{l}1.75 \\
\text { V/cell }\end{array}$ & $\begin{array}{l}\text { Not } \\
\text { Good }\end{array}$ \\
\hline $\begin{array}{l}\text { Pasir } \\
\text { bitung_Tb }\end{array}$ & $4 \mathrm{H}$ & $44.7 \mathrm{VDC}$ & $\begin{array}{l}1.86 \\
\text { V/cell }\end{array}$ & $\begin{array}{l}\text { Not } \\
\text { Good }\end{array}$ \\
\hline
\end{tabular}

After the charge-discharge process was carried out on the new VRLA battery and tested on site, it was found that the condition of the batteries in two locations did not provide good performance as shown on Table 7. This might be due to the lock moment on the battery bolt is too tight or even too loose which results in a decrease in the supply ability of the battery.

\section{E. Analysis of Inter-cell battery bolt torque}

A torque wrench is a tool to turn bolts and nuts on a tool with a certain level of tightness. This is important, because inaccurate and unmeasured torque measurements such as when using hands, or an ordinary wrench can be fatal for the device. For example, in the installation of bolts and nuts on a battery that will experience heating from the chemical reaction of the battery, the reaction will cause uneven expansion of the surface or rods of bolts and nuts. So, if the lock is too tight or too loose it can cause a decrease in the battery supply capability.

The magnitude of the torque value is determined by the type, size, and also the grade of the bolt material. For the 170AH VRLA battery, the terminal specifications of the M6 battery are equivalent to $d=0.236 \mathrm{~m}$. then the force required to tighten the battery nut with a torque of $9-11 \mathrm{Nm}$ is:

$$
\begin{gathered}
T=F x r \\
F=\frac{T}{r} \\
F=\frac{10}{\frac{1}{2} \cdot 0,236} \\
=84,74 \mathrm{~N}
\end{gathered}
$$

\section{F. Analysis of the effect of rectifier module quantity on} the battery charge-discharge process.

Then the next analysis is how many rectifiers are required according to the load on site. Rectifier is a device to convert alternating current (AC) into direct current (DC) sources. From this research, three types of rectifier samples in the Sukabumi Cianjur cluster are as follows:

1) Huawei R4850G1 rectifier module

2) Delta DPR2900 rectifier module

3) Eltek FP3000 rectifier module

\begin{tabular}{|c|c|c|c|}
\hline & \multicolumn{3}{|c|}{ Analysis of Rectifier Capacity } \\
\hline & $\begin{array}{c}\text { Huawei } \\
\text { R4850G1 } \\
\text { Module }\end{array}$ & $\begin{array}{c}\text { Eltek } \\
\text { FP2-3000 } \\
\text { Module }\end{array}$ & $\begin{array}{c}\text { Delta } \\
\text { DPR2900 } \\
\text { Module }\end{array}$ \\
\hline $\begin{array}{l}\text { Rated } \\
\text { load }\end{array}$ & $56 \mathrm{~A}$ & $62.5 \mathrm{~A}$ & $56.25 \mathrm{~A}$ \\
\hline $\begin{array}{l}\text { Rectifier } \\
\text { output }\end{array}$ & $53.5 \mathrm{VDC}$ & $53.5 \mathrm{VDC}$ & $54 \mathrm{VDC}$ \\
\hline Total load & $168 \mathrm{~A}$ & $187.5 \mathrm{~A}$ & $168.5 \mathrm{~A}$ \\
\hline $\begin{array}{l}\text { Floating } \\
\text { voltage }\end{array}$ & $53.5 \mathrm{VDC}$ & $53.5 \mathrm{VDC}$ & $54 \mathrm{VDC}$ \\
\hline $\begin{array}{l}\text { Boost } \\
\text { voltage }\end{array}$ & $56.4 \mathrm{VDC}$ & $56.4 \mathrm{VDC}$ & $57.8 \mathrm{VDC}$ \\
\hline$P_{\text {Used }}$ & $1765.5 \mathrm{~W}$ & $2883.7 \mathrm{~W}$ & $3526.2 \mathrm{~W}$ \\
\hline $\mathrm{P}_{\text {available }}$ & $9000 \mathrm{~W}$ & $10031.3 \mathrm{~W}$ & $9112.5 \mathrm{~W}$ \\
\hline Utilization & $18.8 \%$ & $28.7 \%$ & $38.6 \%$ \\
\hline $\begin{array}{l}\text { Rectifier } \\
\text { modules }\end{array}$ & 2 & 2 & 2 \\
\hline $\begin{array}{l}\text { Peak load } \\
(\mathrm{Kc})\end{array}$ & $84 \mathrm{~A}$ & $104.9 \mathrm{~A}$ & $116.2 \mathrm{~A}$ \\
\hline $\begin{array}{l}\text { Module } \\
\text { requirements }\end{array}$ & 2 & 2 & 3 \\
\hline
\end{tabular}

Table 8. Capacity analysis of Rectifier

The need for the rectifier is adjusted to the type of module as listed in Table 8 .

\section{CONCLUSION}

Based on the results of mathematical calculations and then testing in the field, the analysis showed that the condition of the battery that had been carried out in the charge discharge process on the new VRLA battery was then installed at the site on the condition that the AC PLN source was off, only two sites, i.e., Jatinunggal and Mekarsari, which could provide good performance. Sukamaju and Pasir Bitung sites did not provide good performance which might be due to an inappropriate key moment when charging the battery and the number of rectifiers required is adjusted to the type of module and the load of the BTS on site.

The charge-discharge process for a (new) battery is highly recommended, so that the battery is ready to be used for unstable electricity supply by using the C10 and C15 C-rate of the battery capacity to support the fastcharging process.

\section{REFERENCES}

[1] M. Y. Kurriawan Budi Pranata, Muhammad Priyono Tri Sulistyanto, Muhammad Ghufron, "Pengaruh variasi arus pengisian pengosongan muatan pada model baterai lead acid terhadap perubahan efisiensi energi," J. Fis. Flux, Vol. 16, No. 1, Hal. 1-6, 2019.

[2] A. A. Edison Banguero, Antonio Correcher, Ángel PérezNavarro, Francisco Morant, "A review on battery charging and discharging control strategies: application to renewable energy systems edison," Energies 2018, Vol. 11, No. 1, Hal. 1-15, 2018, Doi: 10.3390/En11041021.

[3] T. S. U. Hardik Keshan, Jesse Thornburg, "Comparison of lead-acid and lithium ion batteries for stationary storage in off-grid energy systems," In 4th Iet Clean Energy And Technology Conference (Ceat 2016), 2016, Hal. 1-7, Doi: 10.1049/Cp.2016.1287. 
[4] Yuliza Dan Ardiansyah, "Perancangan lampu taman solarcell otomatis untuk menggunakan microcontroller arduino uno," J. Tek. Elektro Univ. Mercu Buana, Vol. 7, No. 1, Hal. 37-44, 2016.

[5] W. A. Pandyapratita Putra, Andrew Joewono, Rasional Sitepu, Lanny Agustine, "Alat pemantau dan pengendali sistem penyimpanan energi pada solar panel," Sci. J. Widya Tek., Vol. 17, No. 1, Hal. 25-31, 2018.

[6] A. F. Farizy, "Desain sistem monitoring state of charge baterai pada charging station mobil listrik berbasis fuzzy logic dengan mempertimbangkan temperature design of monitoring system of state of charge of battery in a charging station electric car based on fuzzy logic," 2016.

[7] M. Z. E. Wasith Dany Mufty, Dimas Okky Anggriawan, "Baterai charger vrla dengan metode constant current constant voltage berbasis kontrol pi," In Seminar Nasional Terapan Riset Inovatif (Sentrinov) Ke-6, 2020, Vol. 6, No. 1, Hal. 235-243.

[8] Chinashoto.Com V2.0, "6-Fmx Series Front Terminal Battery 6-Fmx-170 Dimensions : ," Chinashoto. 2011.

[9] N. Ricky Agned, "Studi kapasitas baterai $110 \mathrm{vdc}$ pada gardu induk 150 kv bangkinang," Jom Fteknik, Vol. 3, No. 2, Hal. 1-9, 2016.

[10] R. D. Barkah Dan S. Hidayat, "Simulasi charge discharge model baterai lead acid," Jiif (Jurnal Ilmu Dan Inov. Fis., Vol. 03, No. 02, Hal. 128-134, 2019. 